\title{
Gender Differences in Decision-Making During Adolescence: A Comparison of Jewish and Druze Societies
}

\author{
Dr. Fathi Shamma ${ }^{1} \&$ Dr. Eisam Asaqli ${ }^{1}$ \\ ${ }^{1}$ The Arab Academic College for Education in Israel-Haifa \\ Correspondence: Fathi Shamma, The Arab Academic College for Education in Israel-Haifa. E-mail: \\ fsh1308@gmail.com
}

Received: November 18, 2018

Accepted: April 6, 2020 Online Published: April 23, 2020

doi:10.5539/jedp.v10n1p60

URL: http://doi.org/10.5539/jedp.v10n1p60

\begin{abstract}
The principal aim of the study was to compare gender differences in the level of autonomy, parental and peer involvement in the decision-making processes of Jewish and Druze adolescents. The method that was chosen to conduct the study was the qualitative research method and to measure the variables in the current study, a questionnaire containing 30 items was developed. The research population includes 243 participants aged 15-18.

The findings partially confirmed the research hypotheses. The study showed four main findings. First, the study showed that no gender differences are apparent between Jewish and Druze adolescents in the overall degree of autonomy or in parents' and peers' involvement in their decision making. Second, the study revealed that in both groups of adolescents, boys have more autonomy in making decisions relative to girls. The third finding showed that among both male adolescent groups, friends are more involved in their decisions relative to among both female grops. The final finding showed that there is bigger gap in the Druze culture between boys and girls regarding the degree of parental involvement than in the Jewish culture.
\end{abstract}

Keywords: Jewish and Druze societies, decision making, adolescence, autonomy, parents' involvement, peers' involvement, gender differences

\section{Theoretical Background}

\subsection{Decision Making}

Every person makes many decisions each day of their life, Decision making involves choosing between several optional alternatives. Human beings differ in the alternatives they succeed in finding or defining as options, in the degree to which they think these alternatives can solve their present problem and to what extent they evaluate the feasibility of the option. In addition, the ability to develop alternatives and measure the degree of their efficacy evolves throughout time (Poole, Sundberg, \& Tyler, 1982). Decision making comprising many cognitive processes such as searching for and processing information (to gather the details of the alternatives from which they can choose), problem solving (finding a new or creative solution to the present problem), judging (evaluation of the alternatives at hand and choosing the best of them) learning and memory (Mann, Harmoni, \& Power, 1989). Some decisions have important implications for peoples' lives, functioning and success. According to Harren's model (Harren, 1979), which received much empirical support, it is acceptable to relate to three decision making styles: 1. Rational -balanced decision making, which means considering all the information at hand and choosing the best alternative - that one where the profit is bigger than the loss. 2. Dependent - the decision making fits other people's opinions, expectations, and will. 3. Intuitive - emotional decision making that is based on a gut feeling. Later, researchers (Philips, Pazieneza, \& Ferrin, 1984) added another decision-making style to this list - avoidance, which relates to people who try to avoid decision making in any acceptable way, by postponing the decision making or moving the responsibility to make a decision onto other people.

\subsection{The Adolescent as a Decision Maker}

Adolescents world over are required to make many important decisions in a wide range of domains and situations (Franken \& Muris, 2005). For example, during high school, students are required to make decisions regarding the school they are willing to study in as well as the subjects they wish to study, decisions that will affect their future studies and the professional options they will face (Bonnie, Flesher, \& Cauffman, 2001; Tunistera, Van Sonderen, Groothoff, Van Den Heuvel, \& Post, 2000). According to a great number of studies, adolescents ascribe much 
importance to these studying decisions and to career option choices. Freidman's research (1998), carried out among Israeli adolescents, also found that decisions related to studies occupy adolescents more than other decisions. The decisions that a person makes during their adolescence period, such as decisions regarding careers or professions, may have long-term consequences on their professional future, health, emotional well-being, and social position (Gati \& Saka, 2001; Germeijs \& Verscheuren, 2007).

During adolescence, many cognitive abilities, such as collecting and processing data, problem solving, judging, memory and learning, are developed and improve the adolescent's ability to make decisions by themselves. Furthermore, at this age, adolescents are emotionally well-developed and have more self-control, greater ability to take responsibility for their own decisions, and an increased awareness regarding the consequences and risks inherent in their decisions. At the age of fifteen, approximately, most adolescents are able to make decisions at a level similar to adults and show the capacity to pick the correct option and solve problems creatively (Lewis, 1989; Mann et al., 1989). As a result of this cognitive and psychological development, adolescents feel a strong need for autonomy and independence, which is manifested by a strong determination to make decisions by themselves and without others' involvement (Baiocco, Laghi, \& D'Alessio, 2009; Fischoff, 2008; Halpren-Felsher \& Cauffman, 2001; Thunholm, 2004). Moreover, during adolescence, adolescents start being skeptical regarding their parents' authority for making decisions for them in domains such as studying habits, friends, and leisure activities, and they demand to be allowed to make decisions about themselves independently (Franken \& Muris, 2005).

\subsection{Differences Between Druze and Jewish Adolescents in Autonomy, and Parents' and Peers' Involvement}

Because the Druze culture is collectivistic while the Jewish culture is individualistic, it is possible to think that Jewish adolescents receive more autonomy and independence in making decisions versus Druze adolescents. Surprisingly, however, a study that compared the parental styles of 11th graders from both cultures shows that Druze students reported being given more autonomy by their parents in making decisions than their Jewish counterparts (Seginer et al., 2007). These findings may be explained by the fact that although Jewish parents encourage their children's autonomy and see great importance in developing their independence abilities, their lifestyle and family structure decrease the opportunities for their children to make decisions independently. In contrast, Druze adolescents grow up in big families where parents find it difficult to supervise their children's behavior, and rely on them to take an active role in helping out at home and raising their younger siblings. Furthermore, for Druze adolescents, knowing that in a number of years they will be expected to get married and support themselves as well as their new families, contributes to their feeling of independence. As a result, Druze adolescents gain the skills of autonomy and readiness for life faster than their Jewish equivalents, including making crucial decisions (Seginer, 1992; Seginer et al., 2007).

In addition, contrary to what has been found regarding the differences between individualistic and collectivistic cultures in different places in the world, no differences were found between Druze and Jews in Israel in the development of an increasing sense of autonomy in adolescents during their adolescence years. In both cultures, the older the adolescents got, the more autonomy they receive (Wainrby, 1997). In the Jewish culture, adolescence often lasts to the late end of their twenties, until their professional, familial, and social identity are shaped (Ericson, 1961). Jewish adolescents' relations with their parents are characterized, in most cases, by support, closeness, and warmth, which contribute to adolescents' self-searching process and lets them call upon their parents at times of need and adversity (Hareal et al., 1997; Mayseless, Wiseman, \& Hai, 1998; Scharf \& Mayseless, 2005). Still, according to studies in this field, Jewish adolescents' relations with their parents in Israel have some problematic aspects, especially regarding setting clear borders between parents and their adolescents as well as parental authority vis-à-vis their children (Hareal et al., 1997; Omer, 2008).

In a number of studies carried out among Jewish adolescents studying in a junior high (Mayseless, 2001) and a high school (Scharf \& Mayseless, 2001), the participants reported a low level of behavioral control by parents as well as parental difficulty in imposing their authority on their adolescents. Also, Mayseless and Scharf's study (2009), which tested different characteristics of Israeli Jewish adolescents' relations with their parents, shows that only $33 \%$ of Jewish adolescents reported an authoritative parental pattern that manifested iteself in combining love, warmth, and the setting of clear borders. $22 \%$ of the adolescents did report parental patterns characterized by a combination of parents' excessive involvement in their lives and significant behavioral control including offensive punishment - patterns creating many clashes between adolescents and their parents. About $30 \%$ of the adolescents reported a yielding parental pattern manifested in a mix of parental support and warmth and not setting clear borders, or even without an expectation of obeying laws and authority. In a small number of cases $(15 \%)$, the adolescents reported neglecting and offensive parental patterns that do not include warmth or support, do not set clear borders for children, and behave towards them in an offensive and controlling way, including severe 
punishment, psychological control and clashes (Mayseless \& Scharf, 2009).

Because the Druze culture is collectivistic, Druze adolescents see themselves as more obligated than Jewish adolescents to their family's well-being, to being loyal to their extended family, and to its needs, which come before their personal needs (Dana, 1998; Nydel, 1987). This strong obligation mostly creates in them a sense of belonging (Barakat, 1993). As a result, adolescence as a period of identity searching is shorter in this culture, and Druze adolescents tend to support themselves and start a family at a younger age (Khieradeen, 2005). Furthermore, due to the hierarchal familial structure, parents conduct a "bottom to top" connection with their adolescents in the shape of instructions, orders, warnings or threats. This conduct creates, in most adolescents, an external control focus, where they feel the control over their life is put in their parents' hands, while their personal characteristics — such as skills or talents - have less impact on the process of their lives (Barakat, 1993).

In addition, parents in the Druze culture are considered a source for consultation and direction while less as an emotional crutch for adolescents in comparison to the Jewish culture. Druze adolescents' relations with their siblings are close, apparently because these relations compensate for the emotional lack in their relations with their parents (Seginer et al., 2007). It is important to mention that in the Druze culture there are some differences between fathers and mothers in terms of their relations and connections with their adolescents. Fathers are the source of power in this culture and they make most of the decisions, relative to the mothers. On the other hand, in the Jewish culture, mothers and fathers have similar power and authority in making decisions for their children (Weller et al., 1995).

Regarding the connection of Druze adolescents with their peers, previous studies show there are less close friendly and intimate connections between adolescents and their peers of the same age and gender, as opposed to in the Jewish culture. Still, the degree of importance that Druze adolescents relate to their peers and to the extent of how close they feel to them is higher than in the Jewish culture. Furthermore, Jewish adolescents receive more emotional and social support from their peers, especially in cases where their relations with their parents do not provide them with satisfying warmth and support, as opposed to the Druze culture.

\subsection{Differences Between the Genders in the Druze and Jewish Cultures}

In the current research, the factors affecting decision making by adolescent Jews and Druze, especially the differences between the genders, is compared. One significant difference between the Druze and Jewish cultures, similar to the differences between individualistic and collectivistic cultures (in different places of the world), is the status and treatment girls and boys receive from their society and parents. In the Jewish culture, there are no big gaps between the opportunities that male and female adolescents face when it comes to deciding on a subject to study, advanced studies, a spouse, or other significant decisions. Both genders receive relatively similar freedom of choice. This relative equality derives from the significant changes in women's status in the Jewish culture in recent decades (Greene \& DeBacker, 2004; Kahat, 2003).

In comparison to the Jewish culture, women and children in the Druze culture are controlled to a great degree by men. Girls are expected to behave and conform. Decisions related to occupation, career, or a spouse are regulated by familial expectations and made by the fathers (Barakat, 1993; Haj-Yehia, 1995; Sharabany, 2006). Thus, Druze women's space for making decisions related to academic paths and profession is significantly diminished in comparison to women in the Jewish culture (Falah-Faraj, 2005). In a study conducted in the middle of the 1990s, the results showed that most Druze (adolescents and adults) believed that men have the authority to decide for their daughters and wives in a wide range of domains (including studies, occupation, choosing friends and leisure activities), and if women or daughters are interested in taking part in activities that fathers reject, they must eventually obey their head of family (Wainbryb \& Turiel, 1994).

According to data from the 1980s, less than half of the Druze women finished elementary school, and only $25 \%$ of them finished high school. In contrast, $86 \%$ of the Druze boys finished elementary school and $36 \%$ of them finished high school. Furthermore, girls had to receive their fathers' (or husbands' - once married) permission to start working, and when they do start, they relinquish most of their income to them (Wainryb \& Turiel, 1994). In addition, until the 1990s, Druze women were prohibited from driving, being in public places, going to cinemas or museums, listen to concerts, watch theaters, sit in coffee shops, or go shopping. Such activities were perceived as immoral, and threatening the family's dignity and the women's lives in a critical way (Hasan, 1999). The cultural rejection regarding women wanting to acquire education and a profession stemmed from the fear of many parents that education may turn their daughters into more assertive and independent woman incapabie of or unwilling to adapt to the norms and behaviors of traditional Druze culture (Nasef, 1992). Instead of acquiring a profession, Druze women used to get married at an early age as a result of parents' mediation from both sides (As-Sadawi, 1988). 
Another aspect of the differences in Druze parents' treatment towards their male and female adolescents is related to the great degree in supervising and controlling the decisions that their children make. Studies on the degree of parental involvement in Arab male and female adolescents' lives showed that parents control their daughters' behavior and decisions more than they do so their sons. For example, it is culturally acceptable that Arab parents demand that their daughters provide them with details about their friendships, while they might not do the same with their sons. In parallel, Arab female adolescents depict an intimate connection with their parents, relatively to males, which is manifested in sharing troubles they face in academia or society more with their parents than male adolescents do (Azaiza, 2005).

Due to the similarity between Druze and Arab lifestyles, it is possible to hypothesize that such findings would also reflect Druze parents' relations with their maturing daughters. It is important to mention that over the last decade, the Druze culture has been becoming more liberal and modern, and now allows women to make more independent decisions during adolescence and at a later age too (Seginer et al., 2007). As a result, nowadays, a high percentage of Druze girls finish high school, study in universities, and go to work outside the house. Still, the percentage of these girls/women is significantly lower than that in the Jewish culture (Weller et al., 1995). Furthermore, a study carried out in 2004 showed that Druze female students framed most of their ambitions in the range of family, marriage, and education, while male students focused more on domains of work and career (Greene \& DeBacker, 2004).

\section{Methodology}

\subsection{Research Method}

The method that was chosen to conduct the study was the qualitative research method, using an in-depth structured questionnaire. The qualitative method places the emphasis on how people understand and interpret their personal world and helps us understand in the best way their behaviors and thoughts (Shkadi, 2003). Further, the method tries to understand how they interpret their way of life and helps us recognize their viewpoints and understand how they understand things (Tzabar Ben-Yehoshua, 1990).

\subsection{Research Tools}

To measure the variables in the current study, a questionnaire containing 30 items was developed. The items are measured through Likert scale having five degrees. Participants were asked to rate their degree of agreement with each item from 1 (disagree at all) to 5 (quite agree).

\subsection{Research Population}

In the present study, 243 participants aged 15-18 took part, 124 Druze (51\%) and 119 Jews (49\%). The sample included 131 girls (53.9\%) and 112 boys (46.1\%). Jewish students were chosen from schools in Nahariyya (grades - 10, 11, 12), and Kfar Vradim (grades - 9), while Druze students were chosen from schools in Yarka (grades 9-12), Horfeish (grades - 10 and 11), and Beit Jann (grades - 12).

The division according to grades was as follows:

Grade 9 - 32 Jews and 28 Druze

Grade 10 - 30 Jews and 32 Druze

Grade $11-31$ Jews and 34 Druze

Grade 12 - 31 Jews and 25 Druze

\subsection{The Study Hypotheses e}

1) Druze and Jews male adolescents have more autonomy in decision making relative to females.

2) In the Druze and Jews cultures, parents are more involved in females' decision making relative to the males' decision making.

3) In the Druze and Jews cultures, friends' involvement in females' decision making is more significant than it is among males' decision making. 
Table 1. The number of males and females (in percentage) in the sample according to grades and sectors

\begin{tabular}{|c|c|c|c|c|}
\hline \multirow{2}{*}{ Grade } & \multirow{2}{*}{ Gender } & \multicolumn{2}{|c|}{ Sector } & \multirow{2}{*}{$\begin{array}{l}\text { Difference } \\
\text { Examination }\end{array}$} \\
\hline & & Druze & Jews & \\
\hline \multirow{2}{*}{9} & Boys & 34.4 & 53.6 & \multirow{2}{*}{$\mathrm{X}^{2}=2.24, \mathrm{n} . \mathrm{s}$} \\
\hline & Girls & 65.6 & 46.4 & \\
\hline \multirow{2}{*}{10} & Boys & 53.3 & 43.8 & \multirow{2}{*}{$\mathrm{X}^{2}=0.57$, n.s. } \\
\hline & Girls & 46.7 & 56.3 & \\
\hline \multirow{2}{*}{11} & Boys & 41.9 & 44.1 & \multirow{2}{*}{$\mathrm{X}^{2}=0.03$, n.s. } \\
\hline & Girls & 58.1 & 55.9 & \\
\hline \multirow{2}{*}{12} & Boys & 51.6 & 48.0 & \multirow{2}{*}{$\mathrm{X}^{2}=0.07$, n.s. } \\
\hline & Girls & 48.4 & 52.0 & \\
\hline \multirow{2}{*}{ Total } & Boys & 45.2 & 47.1 & \multirow{2}{*}{$\mathrm{X}^{2}=0.09, \mathrm{n} . \mathrm{s}$} \\
\hline & Girls & 54.8 & 52.9 & \\
\hline
\end{tabular}

\section{Discussion}

As the table shows, no clear differences were found between Druze and Jewish males and females in the division into grades.

The first significant issue chosen in the current study referred to the differences between the genders in three factors that influence adolescents' decision making. The fourth hypothesis in the current study was that boys from both study groups have more autonomy in making decisions relative to girls. According to the results, this hypothesis was partially approved. Regarding autonomy, no differences were found in the two study groups between boys and girls in the degree of general autonomy and in some types of decision making, but in other types there were some differences. These hypotheses are based on studies that show that although there is an improvement in women's status and in the equality between women and men in recent years, parents still tend to encourage their sons to have more autonomy in decision making while they encourage their daughters to have more empathy, self-exposure, and physical closeness (Lytton \& Romney, 1991).

Despite finding similar results for both sectors in the current study, it is important to relate to each one separately due the differences found in the past between them when relating to boys and girls. Although past studies showed that boys received more autonomy in the Jewish culture, and in individualistic cultures generally, it was found that girls perceive themselves as more independent than boys while receiving from their parents more autonomy in decision making, versus boys, simply because they are perceived as more mature and have better decision-making abilities (see, for an example, Bampus et al., 2001; Shamma \& Katz, 2018).

It is probable that the lack of findings regarding the differences between boys and girls in the current study reflects a decrease in the difference between the genders while referring to more equal treatment for boys and girls in this culture - the Jewish culture. It is important to mention that this finding is supported in part of the studies in the field that referred to equality between women and men in the Jewish culture in the opportunities they face, while in some of these opportunities they make decisions regarding career or a spouse independently (Greene \& DeBcker, 2004).

Regarding the Druze culture, according to previous results related to this culture and to collectivistic cultures generally, one of the salient phenomena was the application of a different treatment for boy and girls. Boys are perceived as having a higher status than girls, while they mostly receive more autonomy than girls, and there is an expectation that they should make decisions independently so they can prepare themselves for the independent life they are going to start soon. The traditional perception regarding girls is that the head of the family, the father, makes all of the significant decisions (career, spouse, or studies) on behalf of the girls, while they are expected to conform. In other words, girls have fewer opporunities to make decisions independently (see Barakat, 1993). According to the findings of the current study, the differences between the genders in the Druze culture in the factors that influence decision making have diminished. Today, the fact that Druze women study in the universities or go to work outside the house is strong support of the change through which the Druze culture is going and of the increasing degree of independence and autonomy Druze women receive (Greene \& DeBecker, 2004). 
In a more profound examination of this issue and the analysis of multivariable differences, the results show that there are differences between the two sectors only in two aspects of autonomy that boys reported having more than girls - making independent decisions regarding academic choices, and making independent decisions without consulting with anyone at all. This finding probably reflects a stronger need of boys to stress their independence and the historical tendency in the two cultures of giving boys a wider space of independence over girls.

The second hypothesis of the current study relates to the differences between the genders in the degree of adolescent friends' involvement. This hypothesis was partially suppported. In both groups, no differences were found between boys and girls in the general degree of friends' involvement in decisions adolescents make, while there were some differences in some types of decisions that male and female adolescents make. It is possible to explain these findings through a relation to differences between the genders in their social interactions with their friends and to the quality of such connections that they build. According to many studies, girls create a close intimate connection with one female friend or two - a connection based on mutual support, self exposure, empathy, and cooperation. As a result, they would share with their friends their confusions, emotions, and thoughts they have regarding any decision, in the process of making a decision. On the other hand, boys tend to create more superficial connections, but are still more influenced by their friends' opinions and by social pressure that makes it difficult for them to act against their friends' attitudes (Brown et al., 1986; Rose \& Rudolph, 2006). In other words, it is possible that boys and girls feel that their friends are involved in their decisions, but the process of the influence and the way this happens are different between the two genders. There is a need for more profound future studies to understand the process of such involvement.

Besides examining the differences in the general degree of friends' involvement, a comparison between the genders in the different types of decision making was carried out. The analysis of the multivariable differences showed that it is more important for girls to listen to their friends' opinions when making important decisions, and that their friends are more involved in every decision they make. Boys pointed out that they, in contrast, tend to make decisions without consulting their friends, but their friends are still involved in decisions related to places and times of recreation. These findings may be explained primarily through the differences ascribed to the relations that boys and girls create with their friends. Girls, due to the intimate connection with their female friends, would feel a stronger need of sharing with them decision making, especially regarding important decisions. The last hypothesis in the current study was that in the Druze culture, there will be a bigger gap between male and female adolescents in the degree of friends' and parental involvement than in the Jewish culture. This hypothesis was disapproved. A higher degree of parental involvement was found in girls' decisions in different domains, compared to boys, in both sectors without significant differences between them. This hypothesis derived from the fact that in traditional Druze culture, parental involvement in girls' decisions is more acceptable compared to boys (Barakat, 1993). In addition, previous studies carried out among Arab girls showed that parents supervise their daughters' actions and behavior more than they do their sons (Azaiza, 2005). On the other hand, there are no big gaps between the genders in making significant decisions regarding their lives (Greene \& DeBecker, 2004).

\section{Conclusions}

Regarding the Druze culture, the findings match the previous studies described above. Regarding the Jewish culture, however, the current study shows that although Jewish girls have equal opportunities to boys, their parents still feel a strong need to protect them and be more involved in the decisions related to their relations with boys, despite having a higher degree of autonomy in making independent decisions. It is possible to say that these findings might reflect similar processes between both sectors, which derive from stereotypical differences between the genders and from a stronger need to protect girls, while they less refer to differences between the sectors when referring to differences between boys and girls. There is a need for further study in the future that can examine to what extent the degree of parental involvement in decisions that girls make is derived from the same basic process or from different processes in both sectors.

\subsection{Recommendations}

The current research, because it is the first in this field, raises extensive research questions that call for a thorough investigation of this topic in the future. First, it is recommended that similar research be conducted with a more diverse population and with additional research tools in order to solve methodical limitations. Second, it is recommended that the viewpoint of the parents and friends of adolescents be tested, in addition to that of the teenagers themselves, so as to obtain a deeper understanding of the factors influencing their decision making. A third recommendation is to perform a longitudinal study that can examine the development of this issue and the impact age makes on the degree of autonomy, friends' involvement and parents' involvement in the adolescents' decision-making process, as well the differences between males and females in different age groups. 


\section{References}

Azaiza, F. (2005). Parent-child relationships as perceived by Arab adolescents living in Israel. International Journal of Social Welfare, 14(4), 297-304. https://doi.org/10.1111/j.1369-6866.2005.00372.x

Baiocco, R., Laghi, F., \& D’Alessio, M. (2009). Decision Making style among adolescents: Relationship with sensation seeking and locus of control. Journal of Adolescence, 32(4), 963-976. https://doi.org/10.1016/j.adolescence.2008.08.003

Bampus, M. F., Crouter, A. C., \& McHale, S. M. (2001). Parental autonomy granting during adolescence: Exploring gender differences in context. Developmental Psychology, 37(2), 163-173. https://doi.org/10.1037/0012-1649.37.2.163

Bao, X. H., \& Lam, S. F. (2008). Who makes the choice? Rethinking the role of autonomy and relatedness in Chinese children's motivation. Child Development, 79(2), 269-283. https://doi.org/10.1111/j.1467-8624.2007.01125.x

Barakat, H. (1993). The Arab world: Society: culture and state. Berkeley, CA: University of California Press.

Barber, B. K., \& Olsen, J. A. (1997). Socialization in context: Connection, regulation and autonomy in the family, school and neighborhood and with peers. Journal of Adolescent Research, 12(2), 287-315. https://doi.org/10.1177/0743554897122008

Barber, B. K. (1996). Parental psychologic control: Revisiting a neglected construct. Child Development, 67(6), 3296-3319. https://doi.org/10.2307/1131780

Barber, B. K., Stolz, H. E., Olsen, J. A., Collins, W. A., \& Burchinal., M. (2005). Parental support, psychological control and behavioral control: Assessing relevance across time, method and culture. Monographs of the Society for Research in Child Development, 70(4), 1-147.

Bardick, A. D., Bernes, K. B., Magnusson, K. C., \& Witko, K. D. (2004). Junior high career planning: What students want. Canadian Journal of Counseling, 38(2), 104-117.

Baumrind, D. (2005). Patterns of parental authority and adolescent autonomy. New Direction for Child and Adolescent Development, 2005(108), 61-69. https://doi.org/10.1002/cd.128

Bonnie, L., Flesher, H., \& Cauffman, E. (2001). Costs and benefits of decision-making competence in adolescents and adults. Applied Developmental Psychology, 22(3), 257-273. https://doi.org/10.1016/S0193-3973(01)00083-1

Brown, B. (2004). Peer groups and peer cultures. In S. S. Feldman \& G. R. Eliot (Eds.), At the threshold: The developing adolescent (pp. 171-196). Cambridge, MA: Harvard University Press.

Brown, B., Clasen, D. R., \& Eicher, S. A. (1986). Perceptions of peer pressure, peer conformity dispositions, and self reported behavior among adolescents. Developmental Psychology, 22(4), 521-530. https://doi.org/10.1037/0012-1649.22.4.521

Bush, K. R., Supple, A. J. \& Lash, S. B. (2004). Mexican adolescents' perceptions of parental behaviors and authority as predictors of their self-esteem and sense of familism. Marriage \& Family Review, 36(1-2), 35-65. https://doi.org/10.1300/J002v36n01_03

Chao, R., \& Tseng, V. (2002). Parenting of Asians. In M. H. Bornstein (ed.), Handbook of Parenting (Vol. 4): Social conditions and applied parenting (pp. 59-94). Abingdon, UK: Lawrence Erlbaum Associates Publishers.

Chao, R. K. (2001). Extending research of the consequences of parenting style for Chinese Americans and European Americans. Child Development, 72(6), 1832-1843. https://doi.org/10.1111/1467-8624.00381

Chen, X., French, D. C., \& Schneider, B. H. (2006). Peer relationships in cultural context. Cambridge, MA: Cambridge University Press. https://doi.org/10.1017/CBO9780511499739

Chi-Cheung, C. S. S., \& Pomerantz, E. M. (2011). Parents' involvement in children's learning in the United States and China: Implications for children's academic and emotional adjustment. Child Development, 82(3), 932-950. https://doi.org/10.1111/j.1467-8624.2011.01582.x

Collins, W. A. \& Steinberg, L. (2006). Adolescent development in interpersonal context. In N. Eisenberg, W. Damon \& R. Lerner (Eds.), Handbook of child psychology, Vol 3: Social, emotional and personality development (pp. 1003-1067). New York, NY: Wiley. https://doi.org/10.1002/9780470147658.chpsy0316 
Collins, W. A., \& Laursen, B. (2004). Parent- adolescent relationship and influences. In R. M. Lernaer \& L. Steinberg (Eds.), Handbook of adolescent psychology (2nd ed.) (pp. 331-361). New-York, NY: Wiley. https://doi.org/10.1002/9780471726746.ch11

Coltrane, A., \& Adams, M. (2008). Gender and families. Lanham, Md.: Rowman \& Littlefield.

Cooper, C. R., Baker, H., Polichar, D., \& Welsh, M. (1993). Values and communication of Chinese, Filipino, European, Mexican and Vietnamese American adolescents and their families and friends. New Directions for Child and Adolescent Development, 62, 73-89. https://doi.org/10.1002/cd.23219936207

Daddis, C. (2011). Desire for increased autonomy and adolescents' perceptions of peer autonomy: "Everyone else can; Why Can't I'. Child Development, 1310-1326. https://doi.org/10.1111/j.1467-8624.2011.01587.x

Daddis, C. (2008). Influence of Close Friends on the Boundaries of Adolescent Personal Authority. Journal of Research on Adolescence, 18(1), 75-98. https://doi.org/10.1111/j.1532-7795.2008.00551.x

Daddis, C., \& Semtana, J. (2005). Middle class African American families' expectations for adolescents' behavioral autonomy. International Journal of Behavioral Development, 20(5), 371-381. https://doi.org/10.1080/01650250500167053

Darling, N., Cumsille, P., \& Martinez, M. L. (2008). Individual differences in adolescents' beliefs about the legitimacy of parental authority and their own obligation to obey: A longitudinal investigation. Child Development, 79(4), 1103-1118. https://doi.org/10.1111/j.1467-8624.2008.01178.x

Dornbusch, S. M., Carlsmith, J. M., Bushwal, S. J., Ritter, P. L., Leiderman, H., Hastorf, A. H., \& Gross, R. T. (1985). Signal parents extended households and control of adolescents. Child Development, 56(2), 326-341. https://doi.org/10.2307/1129723

Eccles, J. S., Wigfield, A., \& Byrnes, J. (2003). Cognitive development in adolescence. In I. B., Weiner (ed.), Handbook of Psychology: Vol. 6. Developmental Psychology (pp. 325-350). New York, NY: Wiley. https://doi.org/10.1002/0471264385.wei0613

Fischoff, B. (2008). Assessing adolescent decision-making competence. Developmental Review, 28(1), 12-28. https://doi.org/10.1016/j.dr.2007.08.001

Florian, V., Mikulincer, M., \& Weller, A. (1993). Does culture affect perceived family dynamics? A comparison of Arab and Jewish adolescents in Israel. Journal of Comparative Family Studies, XXIV(2), 189-201. https://doi.org/10.3138/jcfs.24.2.189

Fuligni, A. J., Tseng, V., \& Lam, M. (1999). Attitudes toward family obligations among American adolescents with Asian, Latin American and European Background. Child Development, 70(4), 1030-1044. https://doi.org/10.1111/1467-8624.00075

Fuligni, A. J. (1998). Authority, autonomy and parent-adolescent conflict and cohesion: A study of adolescents from Mexican, Chinese, Filipino and European backgrounds. Developmental Psychology, 34(4), $782-792$. https://doi.org/10.1037/0012-1649.34.4.782

Fulligni, A. J., \& Eccles, J. S. (1993). Perceived parent-child relationships and early adolescents' orientation toward peers. Developmental Psychology, 29(4), 622-632. https://doi.org/10.1037/0012-1649.29.4.622

Franken, I., \& Muris, P. (2005). Individual differences in decision making. Personality and Individual Differences, 39(5), 991-998. https://doi.org/10.1016/j.paid.2005.04.004

Gardner M. (2005). Peer influence on risk taking, risk preference and risky decision making in adolescence and adulthood: An experimental study. Developmental Psychology, 41(4), 625-635. https://doi.org/10.1037/0012-1649.41.4.625

Gati, I. \& Saka, N. (2001). High school students career related decision-making difficulties. Journal of Counseling \& Development, 79(3), 331-340. https://doi.org/10.1002/j.1556-6676.2001.tb01978.x

Germeijs, V., \& Verschueren, K. (2007). High school students career decision making process: Consequences for choice implementation in higher education. Journal of Vocational Behavior, 70(2), 223-241. https://doi.org/10.1016/j.jvb.2006.10.004

Goossens, L. (2006). The many faces of adolescent autonomy: Parent-adolescent conflict, behavioral decision making and emotional distancing. In S. Jackson \& L. Goossens (Eds.), Handbook of adolescent development (pp. 135-153). New York, NY: US Psychology Press. 
https://doi.org/10.4324/9780203969861-8

Greene, B. A., \& DeBacker, T. K. (2004). Gender and orientation toward the future: Links to motivation. Educational Psychology Review, 16(2), 91-119. https://doi.org/10.1023/B:EDPR.0000026608.50611.b4

Greenfield, P. M., Keller, H., Fuligni, A., \& Maynard, A. (2003). Cultural pathways through universal

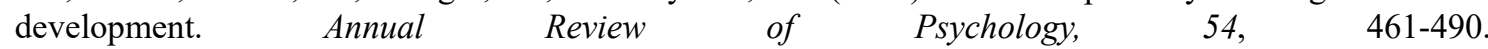
https://doi.org/10.1146/annurev.psych.54.101601.145221

Groinick, W. D., Deci, E., \& Ryan, R. (1997). Internalization within the family: The self-determination theory perspective. In J. E. Grusec \& L. Kuczynski (Eds.), Parenting and children's internalization of values: A handbook of contemporary theory (pp. 135-161). New York, NY: Wiley.

Gutman, L. M., \& Eccles, J. S. (2007). Stage-environment fit during adolescence: Trajectories of family relations and adolescent outcomes. Developmental Psychology, 43(2), 522-537. https://doi.org/10.1037/0012-1649.43.2.522

HajYahia, N. M. (1995). Toward culturally sensitive intervention with Arab families in Israel. Contemporary Family Therapy, 17(4), 429-447. https://doi.org/10.1007/BF02249355

Halpern-Felsher, B. L., \& Cauffman, E. (2001). Costs and benefits of a decision: Decision making competence in adolescents and adults. Journal of Applied Developmental Psychology, 22(3), 257-273. https://doi.org/10.1016/S0193-3973(01)00083-1

Harren, V. A. (1979). A model of career decision-making for college students. Journal of Vocational Behavior, 14(2), 119-133. https://doi.org/10.1016/0001-8791(79)90065-4

Hartup, W. H. (1993). Adolescents and their friends. New Directions for Child Development, 60, 3-22. https://doi.org/10.1002/cd.23219936003

Hasebe, Y., Nucci, L., \& Nucci, M. (2004). Parental control of the personal domain and adolescent symptoms of psychopathology: A cross- national study in the U.S.A and Japan. Child Development, 75(3), 815-828. https://doi.org/10.1111/j.1467-8624.2004.00708.x

Hill, J. P., \& Holmback, G. N. (1986). Attachment and autonomy during adolescence. Annals of Child Development, 3, 145-189.

Ho, D. (1986). Chinese patterns of socialization: Critical review. In M. Bond (Ed.), The psychology of Chinese people (pp. 1-37). New York, NY: Oxford Press.

Israelashvili, M., Taubman-Ben-Ari, O., \& Hochdorf, Z. (2011). A multidimensional approach to explore cross-cultural differences in coping behavior: Comparing Druze and Jews in Israel. The Journal of Social Psychology, 151(1), 31-50. https://doi.org/10.1080/00224540903366651

Iyengar, S., \& Lepper, M. (1999). Rethinking the value of choice: A cultural perspective on intrinsic motivation. Journal of Personality and Social Psychology, 76(3), 349-366. https://doi.org/10.1037/0022-3514.76.3.349

Lake-Mary, L., Crouter, C. A., \& Mchale, S. (2010). Developmental patterns in decision making autonomy across middle childhood and adolescence: European American parents' perspectives. Child Development, 81(2), 636-651. https://doi.org/10.1111/j.1467-8624.2009.01420.x

Lamborn, S. D., Dornbusch, S. M., \& Steinberg, L. (1996). Ethnicity and community context as a moderator of relations between family decision making and adolescent adjustment. Child Development, 67(2), 283-301. https://doi.org/10.2307/1131814

Laursen, B., \& Collins, W. A. (2009). Parent-child relationships during adolescence. In R. M. Lerner, \& L. Steinberg (Eds.), Handbook of adolescent psychology (3rd ed., pp. 3-42). Hoboken, NJ: Wiley. https://doi.org/10.1002/9780470479193.adlpsy002002

Lewis, C. (1981). How adolescents approach decisions: changes over grade seven to elven and policy implications. Child Development, 52(2), 538-544. https://doi.org/10.2307/1129172

Lytton, H., \& Romney, D. M. (1991). Parents' differential socialization of boys and girls: A meta-analysis. Psychological Bulletin, 109(2), 267-296. https://doi.org/10.1037/0033-2909.109.2.267

Mann L., Harmoni, R., \& Power, C. (1989). Adolescent decision making: The development of competence. Journal of adolescence, 12(3), 265-278. https://doi.org/10.1016/0140-1971(89)90077-8

Markus, H. R., \& Kitayama, S. (1991). Culture and the self: Implications for cognition, emotion and motivation. 
Psychological Review, 98(2), 224-253. https://doi.org/10.1037/0033-295X.98.2.224

Mayseless, O., Wiseman, H., \& Hai, I. (1998). Adolescents' relationship with father, mother and same gender friend. Journal of Adolescent Research, 13(1), 101-123. https://doi.org/10.1177/0743554898131006

Mikulincer, M., Florian, V., \& Weller, A. (1993). Attachment styles, coping strategies and Post Traumatic Psychological Distress. Journal of Personality and Social Psychology, 64(5), 817-826. https://doi.org/10.1037/0022-3514.64.5.817

Nashef, Y. (1992). The psychological impact of the Intifada on Palestinian children living in refugee camps in the West Bank, as reflected in their dreams, drawings and behavior. Frankfurt, Germany: Peter Lang Publishers.

Nydell, M. (1987). Understanding Arabs: A guide for Westerners. Yarmouth, ME: Intercultural Press.

Patel, S. G., Salahuddin, N. M., \& O’Brien, K. M. (2008). Career decision-making Self-Efficacy of Vietnamese adolescents: The role of acculturation, social support, socioeconomic status, and racism. Journal of Career Development, 34(3), 218-240. https://doi.org/10.1177/0894845307308488

Perez, J. C., \& Cumsille, P. (2012). Adolescent temperament and parental control in the development of the adolescent decision making in a Chilean sample. Journal of Adolescence, 35(3), 659-669. https://doi.org/10.1016/j.adolescence.2011.09.002

Perez-Brena, N., Updegraff, K. A., and Umana, A. J. (2012). Father- and Mother-Adolescent Decision-Making in Mexican-Origin Families. Journal Youth adolescence, 41(4), 460-473. https://doi.org/10.1007/s10964-011-9660-8

Phillips, S. D., Pazienza, N. J., \& Ferrin, H. H. (1984). Decision making and problem-solving appraisal. Journal of Counseling Psychology, 31(4), 479-502. https://doi.org/10.1037/0022-0167.31.4.497

Poole, M. E., Sundberg, N. D., \& Tyler, L. E. (1982). Adolescents' perceptions of family decision-making and autonomy in India, Australia and the United States. Journal of Comparative Family Studies, XIII(3), 349-357. https://doi.org/10.3138/jcfs.13.3.349

Qin-Hilliard, D. (2003). Gendered expectations and gendered experiences: Immigrant students' adaptation in school. New directions in Youth Development, 100, 91-110. https://doi.org/10.1002/yd.65

Qin, L., Pomerantz, E. M., \& Wang, Q. (2009). Are gains in decision-making autonomy during early adolescence beneficial for emotional functioning? The case of the United States and China. Child Development, 80(6), 1705-1721. https://doi.org/10.1111/j.1467-8624.2009.01363.x

Rose, A. J., \& Rudolph, K. D. (2006). A review of sex differences in peer relationship processes: Potential trade-offs for the emotional and behavioral development of girls and boys. Psychological Bulletin, 132(1), 98-131. https://doi.org/10.1037/0033-2909.132.1.98

Scharf, M., \& Mayseless, O. (2001). The capacity for romantic intimacy: Exploring the contribution of best friend and marital and parental relationships. Journal of Adolescence, 24(3), 379-399. https://doi.org/10.1006/jado.2001.0405

Sebald, H. (1989). Adolescents' peer orientation: Changes in the support system during the past three decades. Journal of Adolescence, 24, 937-946.

Seginer, R., Shoyer, S., Hossessi, R., \& Tannous, H. (2007). Adolescent family and peer relationships: Does culture matter? New Directions for Child and Adolescent Development, 116, 83-99. https://doi.org/10.1002/cd.190

Seginer, R., \& Lilach, E. (2004). How adolescents construct their future: The effect of loneliness on future orientation. Journal of Adolescence, 27(6), 625-643. https://doi.org/10.1016/j.adolescence.2004.05.003

Seginer, R., \& Halabi-Kheir, H. (1998). Adolescent passage to adulthood: Future orientation in the context of culture, age and gender. International Journal of Intercultural Relations, 22(3), 309-328. https://doi.org/10.1016/S0147-1767(98)00010-8

Seginer, R. (1992). Sibling relationships in early adolescence: A study of Israeli Arab sisters. Journal of Early Adolescence, 12, 96-110. https://doi.org/10.1177/0272431692012001006

Shamma, F., \& Katz, M. (2018). Decision Making during Adolescence: A Comparison of Jewish and Druze Societies. International Journal of Psychological Studies, 10(4), 65-78. 
Sharabany, R. (2006). Peer relationships and intimate friendships among Arab and kibbutz children in Israel. In X. Chen, D. C. French \& B. H. Schneider (Eds.), Peer relationships in cultural context (pp. 452-478). New York, NY: Cambridge University Press.

Shkadi, A. (2003). Words that try to touch: Qualitative research - theory and application. Tel Aviv University: Ramot Publications. (Hebrew).

Shulman, S. (1995). Peer group and family relations in early adolescence. International Journal of Psychology, 30(5), 573-590. https://doi.org/10.1080/00207599508246587

Smetana, J. G. (2004). Culture, autonomy and personal jurisdiction in adolescent-parent relationship. Advances in Child Development and Behavior, 29, 51-86. https://doi.org/10.1016/S0065-2407(02)80051-9

Smetana, J. G., Crean, H. F., \& Campione-Barr, N. (2005). Adolescences' and parents' changing conceptions of parental authority. New Directions for Child and Adolescent Development, 108, 31-46. https://doi.org/10.1002/cd.126

Steinberg, L. (2001). We know some things: Parent-adolescent relationship in retrospect and prospect. Journal of Research on Adolescence, 11(1), 1-19. https://doi.org/10.1111/1532-7795.00001

Steinberg, I., Elmeen, J. P., \& Mounts, N. S. (1989). Authoritative parenting psychosocial maturity and academic success among adolescents. Child Development, 60(6), 1424-1436. https://doi.org/10.2307/1130932

Thunholm, P. (2004). Decision making style: Habit, style or both? Personality and Individual Differsnces, 36(4), 931-944. https://doi.org/10.1016/S0191-8869(03)00162-4

Triadis, H. C. (1995). Individualism and collectivism. Boulder, CO: Westview Press.

Tunistra, J., Van Sonderen, F. L. P., Groothoff, J. W, Van Den Heuvel, W. J. A., \& Post, D. (2000). Reliability, validity and structure of the Adolescent Decision-Making Questionnaire among adolescents in The Netherlands. Personality and Individual Differences, 28(2), 273-285. https://doi.org/10.1016/S0191-8869(99)00096-3

Tzabar Ben-Yehoshua, N. (1990). Qualitative research in teaching and learning. Ben Shemen: Modan Publications. (Hebrew).

Wainryb, C., \& Turiel, E. (1994). Dominance, subordination and concepts of personal entitlements in cultural contexts. Child Development, 65(6), 1701-1722. https://doi.org/10.2307/1131289

Wang, Q., Pomerantz, E. M., \& Chen, H. (2007). The role of parents' control in early adolescents' psychological functioning: A longitudinal investigation in the United States and China. Child Development, 78(5), 1592-1610. https://doi.org/10.1111/j.1467-8624.2007.01085.x

Weller, A., Florian, V., \& Mikulincer, M. (1995). Adolescents' reports of parental division of power in a multicultural society. Journal of Research on Adolescence, 5(4), 413-429. https://doi.org/10.1207/s15327795jra0504_2

Winryb, C. (1997). The mismeasure of diversity: Reflections on the study of cross-cultural differences. New Directions for Child and Adolescent Development, 76, 51-65. https://doi.org/10.1002/cd.23219977606

Younnis, J., \& Ketterlinus, R. D. (1987). Communication and connectedness in mother- and father-adolescent relationships. Journal of Youth and Adolescence, 16(3), 265-280. https://doi.org/10.1007/BF02139094

\section{Copyrights}

Copyright for this article is retained by the author(s), with first publication rights granted to the journal.

This is an open-access article distributed under the terms and conditions of the Creative Commons Attribution license (http://creativecommons.org/licenses/by/4.0/). 